Arq. Bras. Med. Vet. Zootec., v.73, n.5, p.1159-1170, 2021

\title{
Econometric ridge regression models of risk-sensitive sunflower yield
}

\author{
[Modelos economométricos de regressão de rendimento de girassol sensível ao risco]
M.I. Slozhenkina ${ }^{1}$ (D) I.F. Gorlov ${ }^{1}$ (D) O.A. Kholodov ${ }^{(1)}$, M.A. Kholodova ${ }^{(1)}$, O.P. Shakhbazova ${ }^{(1)}$, D.A. Mosolova ${ }^{1}$ (D) O.A. Knyazhechenko ${ }^{1}$ \\ ${ }^{1}$ Volga Region Research Institute of Manufacture and Processing of Meat-and-Milk Production, \\ Volgograd, Russian Federation \\ ${ }^{2}$ Rostov State University of Economics, Rostov-on-Don, Russian Federation \\ ${ }^{3}$ Federal Rostov Agrarian Scientific Center, Rostov-on-Don, Russian Federation \\ ${ }^{4}$ Don State Agrarian University, Rostov-on-Don, Russian Federation
}

\begin{abstract}
The article considers econometric ridge regression models of the risk-sensitive sunflower yield on the example of an export-oriented agricultural crop. In particular, we have proved that despite the functional mulcollinearity of the predictors in the sunflower yield model with respect to risk caused by the algorithm peculiarities of the hierarchy analysis methods, the ridge regression procedure makes it possible to obtain its complete specification and provide biased but stable estimates of the forecast parameters in the case of uncertain input variables. It has been substantiated that the rational value of the displacement parameters is expedient to be established using a graphical interpretation of the ridge wake as the border of fast and slow fluctuations in the estimates of the ridge regression coefficients. Econometric models were calculated using SPSS Statistics, Mathcad and FAR-AREA 4.0 software. The empirical basis for forecast calculations was the assessment of trends in sunflower production in all categories of farms in the Rostov region of Russia for the period of 2008-2018. The calculation results of econometric models made it possible to develop three author's scenarios for the sunflower production in the region, namely, inertial, moderate, and optimistic ones that consider the export-oriented strategy of the agro-industrial complex.
\end{abstract}

Keywords: forecasting, agricultural production, export-oriented strategy, econometric models, ridge regression

\section{RESUMO}

O artigo considera modelos econométricos de regressão de rendimento de girassol sensível ao risco sobre o exemplo de uma cultura agrícola orientada para a exportação. Em particular, provamos que apesar da multicolinearidade funcional dos preditores no modelo de rendimento de girassol com relação ao risco causado pelas peculiaridades dos algoritmos dos métodos de análise hierárquica, o procedimento de regressão de cristas permite obter sua especificação completa e fornecer estimativas tendenciosas, mas estáveis dos parâmetros de previsão no caso de variáveis de entrada incertas. Foi comprovado que o valor racional dos parâmetros de deslocamento é conveniente de ser estabelecido usando uma interpretação gráfica da esteira da crista como fronteira das flutuações rápidas e lentas nas estimativas dos coeficientes de regressão da crista. Os modelos econométricos foram calculados usando o software SPSS Statistics, Mathcad e FAR-AREA 4.0. A base empírica para os cálculos de previsão foi a avaliação das tendências da produção de girassol em todas as categorias de fazendas na região de Rostov na Rússia para o período de 2008-2018. Os resultados dos cálculos dos modelos econométricos permitiram desenvolver três cenários de autor para a produção de girassol na região, a saber, os cenários inercial, moderado e otimista que consideram a estratégia orientada à exportação do complexo agroindustrial.

Palavras-chave: previsão, produção agrícola, estratégia orientada à exportação, modelos econométricos, regressão de rendimento

Corresponding author: niimmp@mail.ru

Submitted: March 15, 2021. Accepted: June 8, 2021. 


\section{INTRODUCTION}

Currently, economic forecasting is a scientific prediction of possible trends in development of the economy and a tool for valid substantiating agricultural policy both at the federal and regional levels. The relevance of a reliable forecasting for the agrarian sector and the national economy in general has increased in terms of an emerging trend of strengthened state regulation of socioeconomic processes. However, to understand the agricultural sector of national economy and export-oriented strategies implemented, new analytical approaches are required. Science-based forecasting econometric models serve as the most important tool in the study.

The previously available (until 1990) forecasting methodology has lost both its practical and scientific value due to a new system of strategic planning of the national economy of Russia and trends in the new economic reality. In this regard, it was important to adapt the methodology and forecasting procedures to interpret the laws of the modern national economy that has an unsteadystate path.

\section{METHODS}

The methodological basis of the study was the methods of economic and mathematical modeling, i.e. trend, regression, and simulation modeling.

Trend calculations of the economic processes under study applied linear, logarithmic, power, and exponential models; their functions were

- linear: $Y=a+b x$;

- exponential: $Y_{t}=a b^{t}$;

- power: $Y=a_{0} x_{1}^{n}$; and

- logarithmic: $Y=b=a \ln x$.

However, extrapolation of time series reflecting trends in crop yields cannot always ensure the significance of the indicators predicted; therefore, to assess the trend parameters, several methodological approaches, including regression and simulation modeling (Kuznetsov et al., 2006; Derunova, 2019), should be used simultaneously.

When constructing an econometric model, it was assumed that the independent variables affect the dependent variable in isolation, i.e. the influence of a single variable on the effective trait is not related to the influence of other variables. In reality, all phenomena are connected to any extent; therefore, to achieve this assumption is practically impossible. The relationship between independent variables evidences the need to assess its impact on the results of correlation and regression analysis.

The investigation has proved that the input variables multicollinearity makes the multiple linear regression models based on predictors, having a high strength of correlation between main components, significantly change the estimated regression parameters and determine their incomplete and ambiguous specification. Estimates in particular can have great standard errors and be of low significance, while the model as a whole is adequate (high $\mathrm{R}^{2}$ value). The assumption that multicollinearity of regression models can be eliminated or reduced, using ridge regression methods, has been substantiated (Ivanov et al., 2020; Pokrovsky, 2012).

It was substantiated that the rational value of displacement parameters is expedient to be established using a graphical interpretation of the ridge wake as the border of fast and slow fluctuations in the estimates of the ridge regression coefficients.

The predicted indicator was the sunflower yield. The results of trend and regression modeling were evaluated with respect to in terms of the studied variables and economic, mathematical, and statistical criteria of reliability and accuracy.

\section{RESULTS AND DISCUSSION}

The export of processed products is a factor that positively affects economic relations between agricultural and processing industries. The largest share in the export of food processing industry in the Rostov region belongs to vegetable sunflower oil $(13.0 \%)$. The data of the Federal Customs Service of the Russian Federation indicated that the export of sunflower oil in the Rostov region for the period of 2016-2018 made 2861.7 thousand tons to a value of $\$ 2047.7 \mathrm{mln}$, with the share of sunflower oil produced in the Rostov Region being $30 \%$ of the regional exports, which indicated a developed export infrastructure of the RF constituent entity and growth opportunities for the product sold to other countries. 
In 2018, the Rostov region was ranked 2 nd in the production of refined vegetable oil (specific weight of $14.9 \%$ in the total RF volume) and 3rd in the production of unrefined vegetable oil (specific weight of $10.6 \%$ in the total RF volume) in the Russian Federation (Kholodov, 2020; Goncharov, 2019).

The oil and fat industry of the Rostov region is represented by a number of large oil extraction plants and medium and small enterprises. The main producers of vegetable oil in the Rostov Region are LLC MEZ Yug Rusi and JSC Aston; their combined share in the regional production is more than $80.0 \%$.

On a mid-term horizon, there is a need to assess the commercial opportunities of sunflower processing in the region with respect to the objectives of implemented export-oriented agricultural strategy and substantiate the predicted values based on the econometric models that consider current indices of production of this vitally important type of food in the region up to 2023 (Pechenevsky and Snegirev 2018; Gurnovich, 2018; Poluskina, 2013; Kabanov, 2020).

To predict values of sunflower yield in the Rostov Region, Scenario I was developed based on the analysis of trend series and assessment of the reliability of their results (Fig. 1; Table 1).

According to Table 1, the linear model has the best quality indicators and is characterized with a smaller width of the confidence interval, so it should be accepted for forecasting. Thus, the sunflower yield on the farms of the Rostov region may increase from $19.5 \mathrm{~kg} / \mathrm{ha}$ in 2018 to $26.5 \mathrm{~kg} / \mathrm{ha}$ in 2023 (an increase of 1.4 times).

The next regression model of sunflower production was calculated based on factors affecting the crop yield.

Table 1. Assessed reliability parameters of trending models

\begin{tabular}{ccccc}
\hline Parameter & Linear & Logarithmic & Model & Exponential \\
& & Model quality assessment & \\
$\mathrm{R}^{2}$ & 0.842 & 0.656 & 0.833 & 0.669 \\
$\mathrm{~F}$ & 48.102 & 17.149 & 44.746 & 18.190 \\
Significance F & 0.000 & 0.003 & 0.000 & 0.002 \\
& 26.5 & Forecast model parameters & 32.1 & 20.9 \\
\hline
\end{tabular}

Source: developed by authors according to study results

The multiple linear regression equation took into account the influence of production factors on the sunflower yield level and was formed into

$$
\mathrm{Y}=\mathrm{a}+\mathrm{b}_{1} \mathrm{x} 1+\mathrm{b}_{2} \mathrm{x}_{2}+\mathrm{b}_{3} \mathrm{x}_{3}+\ldots \mathrm{b}_{\mathrm{n}} \mathrm{x}_{\mathrm{n}}, \text { (5) }
$$

where $Y$ is the sunflower yield, $\mathrm{kg} / \mathrm{ha}$; and $\mathrm{x}_{1} \ldots \mathrm{X}_{\mathrm{n}}$ are the factors, affecting the sunflower yield.

The Delphi procedure helped us compile a list of factors that potentially affect the sunflower yield and can be used as a categorical system for predicting the sunflower production. There were considered the following factors:

$x_{1}$ is the ratio of fields under elite seeds in the total area of crops, \%;

$x_{2}$ is the fertilizer applied per 1 ha of sunflower, $\mathrm{kg}$, dose rate;

$x_{3}$ is the plant protection products applied per 1 ha, $\mathrm{L}$, dose rate; $x_{4}$ is the land quality, points;

$x_{5}$ is the proportion of imported sunflower seeds in the total area of crops, \%;

$x_{6}$ is the proportion of sunflower crops in the total area of crops, \%; and

$x_{7}$ is the power equipment per 100 ha of arable land, hp.

Having analyzed the combination of factors with respect to the relationship between the regression and yield, we accepted some features to obtain the function, i.e. $x_{I}$ that is the ratio of fields under elite seeds in the total area of crops, $\% ; x_{3}$ that is the plant protection products applied per 1 ha, L, dose rate; and $x_{5}$ that is the proportion of imported sunflower seeds in the total area of crops, \% [5]. The regression analysis statistics is shown in Table 2 . 


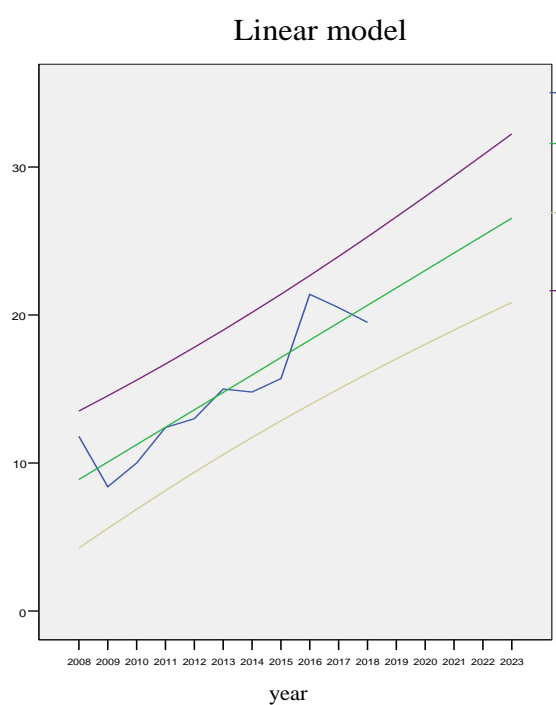

Exponential model

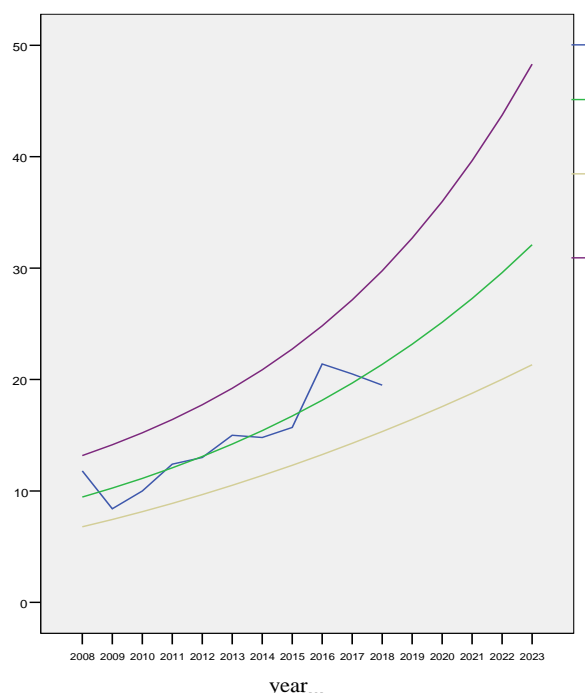

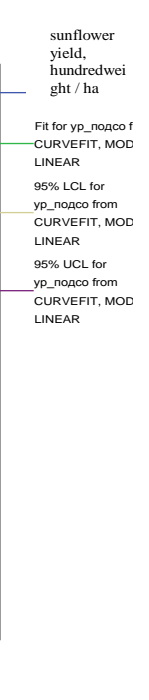

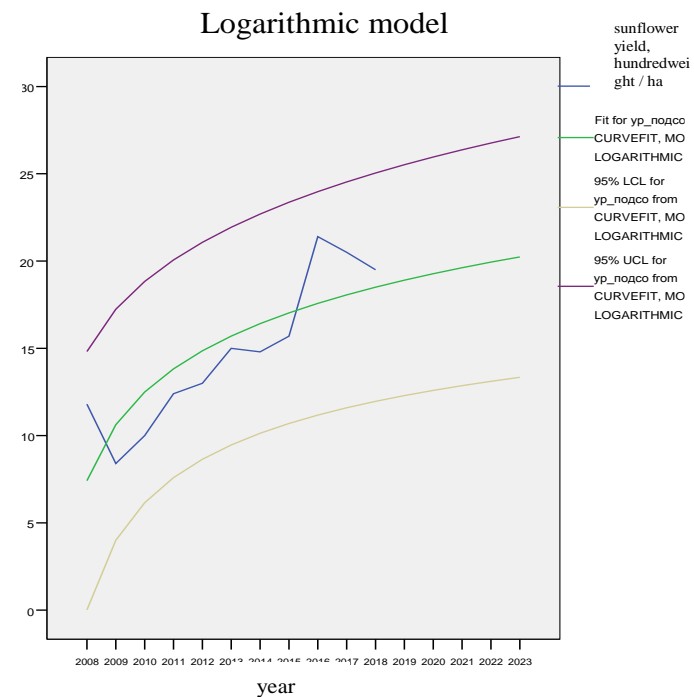

Power model

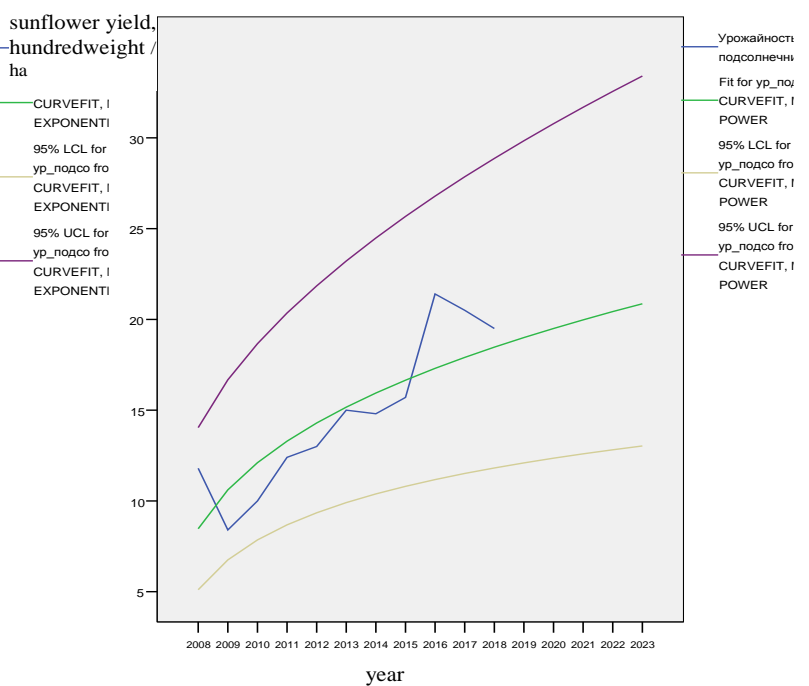

Figure 1. Trend models to forecast sunflower yield in farms of all categories in the Rostov region. Source: developed by authors according to study results

Table 2. Matrix of statistical data for regression analysis of sunflower yield in farms of all categories of the Rostov region

\begin{tabular}{ccccc}
\hline Year & $Y$ & \multicolumn{3}{c}{ Baseline data } \\
\\
2012 & 13.00 & $x_{I}$ & $x_{3}$ & $x_{5}$ \\
2013 & 15.00 & 2.7 & 0.49 & 50.2 \\
2014 & 14.80 & 2.8 & 0.52 & 56.7 \\
2015 & 15.70 & 3.9 & 0.59 & 60.03 \\
2016 & 21.40 & 3.3 & 0.61 & 74.95 \\
2017 & 20.50 & 3.1 & 0.78 & 87.7 \\
2018 & 19.50 & 3.2 & 0.83 & 82.16 \\
\hline
\end{tabular}

Source: compiled by authors according to the Ministry of Agriculture of the Rostov Region 
The relationship between the sunflower yield and main influencing factors was presented as a regression model:

$$
Y=-5.7+3.72 x_{1}+13.32 x_{3}+0.04 x_{5} .
$$

The multiple regression coefficient $\mathrm{R}=0.97$ indicated a close relationship between the whole set of factors and result. The multiple determination coefficient $\mathrm{R} 2=0.95$ suggested that $95.0 \%$ of the variation in sunflower yield was explained by the variation of factors in the model.

However, the assessment of the reliability parameters of the resulting model and the significance of its coefficients indicated that the three-factor model was not adequate, since none of the three factors introduced into the model was statistically significant (Tables 3; 4; and 5). Therefore, the three-factor model (6) cannot be used in predicting the sunflower yield.

The table of coefficients (Table 5) shows that in accordance with the t-criteria and p-levels of their statistical significance, the risk level made $64.8 \%$ for factor $\mathrm{x}_{1}, 19.4 \%$ for factor $\mathrm{x}_{2}$ and $72.7 \%$ for factor $\mathrm{x}_{3}$. Such great risks were unacceptable. The three-factor regression model (6) cannot be recognized as adequate, since the acceptable risk should be not more than $5.0 \%$.

Table 3. Brief general description of regression models ${ }^{\mathrm{d}}$

\begin{tabular}{ccccc}
\hline Model & $\mathrm{R}$ & $\mathrm{R}^{2}$ & Adjusted $\mathrm{R}^{2}$ & Standard error \\
\hline 1 & $0.973^{\mathrm{a}}$ & 0.947 & 0.895 & 1.0629 \\
2 & $0.972^{\mathrm{b}}$ & 0.945 & 0.917 & 0.9428 \\
3 & $0.960^{\mathrm{c}}$ & 0.921 & 0.905 & 1.0073 \\
\hline
\end{tabular}

${ }^{a}$ Independent variables (x) are the ratio of fields under elite seeds in the total area of crops, \%; the plant protection products applied per $1 \mathrm{ha}, \mathrm{L}$, dose rate; and the proportion of imported sunflower seeds in the total area of crops, \%; ${ }^{\mathrm{b}}$ Independent variables $(x)$ are the ratio of fields under elite seeds in the total area of crops, \%; and the plant protection products applied per 1 ha, $\mathrm{L}$, dose rate;

${ }^{\mathrm{c}}$ Independent variable $(x)$ is the plant protection products applied per $1 \mathrm{ha}, \mathrm{L}$, dose rate;

${ }^{\mathrm{d}}$ Dependent variable $(y)$ is the sunflower yield, $\mathrm{kg} / \mathrm{ha}$.

Source: author's calculations

Table 4. Reliability parameters of the regression model

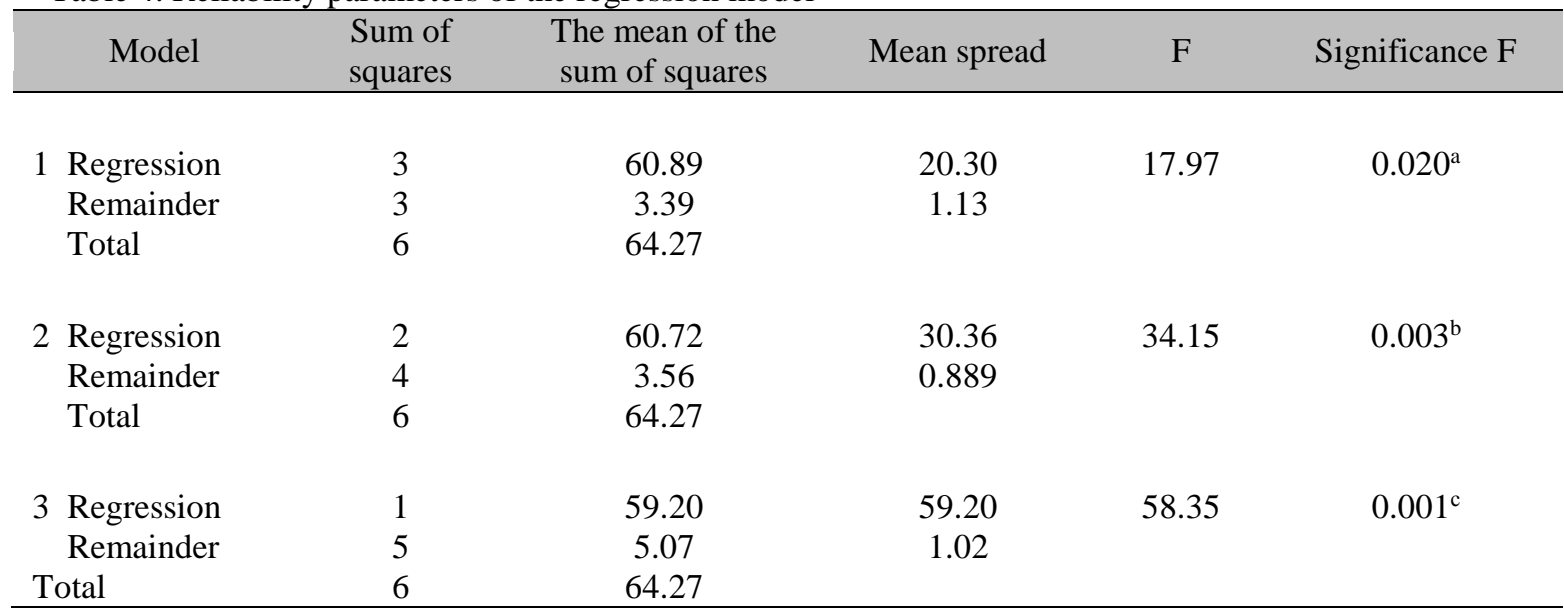

${ }^{\mathrm{a}}$ Independent variables (x) are the ratio of fields under elite seeds in the total area of crops, \%; the plant protection products applied per 1 ha, L, dose rate; and the proportion of imported sunflower seeds in the total area of crops, $\%$;

${ }^{\mathrm{b}}$ Independent variables $(x)$ are the ratio of fields under elite seeds in the total area of crops, \%; and the plant protection products applied per 1 ha, $\mathrm{L}$, dose rate;

${ }^{\mathrm{c}}$ Independent variable $(x)$ is the plant protection products applied per $1 \mathrm{ha}, \mathrm{L}$, dose rate;

${ }^{\mathrm{d}}$ Dependent variable $(y)$ is the sunflower yield, $\mathrm{kg} / \mathrm{ha}$.

Source: author's calculations 
There was applied a step-by-step approach of the regression analysis in the SPSS Statistics program and "Backward" method that enabled reducing the number of independent variables in order to decrease the dimension of the model for all features, insignificant for analysis, being removed; therefore, we simplified the model and obtained results in the form of two-factor and onefactor models (Tables 3; 4; and 5) [11].

Table 5. Model parameters and their levels of significance

\begin{tabular}{|c|c|c|c|c|c|}
\hline & \multicolumn{2}{|c|}{ Unstandardized ratio } & \multirow{2}{*}{$\begin{array}{c}\text { Standardized ratio } \\
\text { Beta }\end{array}$} & \multirow{2}{*}{ t-test } & \multirow{2}{*}{ P-Value } \\
\hline & B & Standard error & & & \\
\hline & & Model 1 & & & \\
\hline (Constant term) & & & & - & \\
\hline & -5.702 & 14.658 & & 0.389 & 0.723 \\
\hline $\begin{array}{l}\text { ratio of fields under elite seeds in } \\
\text { the total area of crops, } \%\end{array}$ & 3.718 & 7.358 & 0.245 & 0.505 & 0.648 \\
\hline $\begin{array}{l}\text { plant protection products applied } \\
\text { per } 1 \text { ha, L, dose rate } \\
\text { proportion of imported sunflower }\end{array}$ & 13.324 & 7.990 & 0.573 & 1.668 & 0.194 \\
\hline seeds in the total area of crops, $\%$ & 0.41 & $\begin{array}{l}0.108 \\
\text { Model } 2\end{array}$ & 0.179 & 0.384 & 0.727 \\
\hline (Constant term) & -9.606 & 9.368 & & $\begin{array}{c}- \\
1.025\end{array}$ & 0.363 \\
\hline $\begin{array}{l}\text { ratio of fields under elite seeds in } \\
\text { the total area of crops, } \% \\
\text { plant protection products applied }\end{array}$ & 5.791 & 4.432 & 0.382 & $\begin{array}{c}- \\
1.307\end{array}$ & 0.261 \\
\hline per 1 ha, $\mathrm{L}$, dose rate & 14.182 & $\begin{array}{l}6.805 \\
\text { Model } 3\end{array}$ & 0.610 & 2.084 & 0.106 \\
\hline $\begin{array}{l}\text { (Constant term) } \\
\text { plant protection products applied }\end{array}$ & 2.395 & 1.966 & & 1.218 & 0.277 \\
\hline per 1 ha, L, dose rate & 22.323 & 2.922 & 0.960 & 7.639 & 0.001 \\
\hline
\end{tabular}

a Dependent variable $(y)$ is the sunflower yield, $\mathrm{kg} / \mathrm{ha}$.

Source: author's calculations

Assessed reliability parameters of the models obtained (Table 4) and the significance levels of their coefficients (Table 5) indicated that the twofactor model cannot be applied for future reference. Although formally it was statistically significant (in Table 4, the significance $F$ was 0.003 ), the variable $x_{5}$ (the proportion of imported sunflower seeds in the total area of crops, \%;) was insignificant, since the risk of $26.1 \%$ was too high to recognize its significance.

Adequate was only one-factor model that included factor $x_{3}$ - the plant protection products applied per 1 ha, L, dose rate. This factor was significant at a high level of 0.001 , so the presented one-factor model was significant. The standard regression equation can be as follows:

$$
Y=2.395+22.323 x_{2} \cdot(7)
$$

When constructing an econometric model, independent variables are assumed to have action on a dependent variable in isolation, i.e. the influence of a single variable on an effective feature is not related to the influence of other variables. Actually, all phenomena are connected to any extent; therefore, to achieve this assumption is practically impossible. The relationship between independent variables evidences the need to assess its impact on the results of correlation and regression analysis.

A correlation between independent variables can be revealed due to correlation indicators between them, in particular, pair correlation coefficients $r \mathrm{XTX}_{\mathrm{X}}$ that can be written as a matrix (8):

$$
r_{x x}=\left(\begin{array}{cccc}
r_{x_{1} x_{1}} & r_{x_{2} x_{2}} & \ldots & r_{x_{1} x_{p}} \\
r_{x_{2} x_{1}} & r_{x_{2} x_{2}} & \ldots & r_{x_{2} x_{p}} \\
\ldots & \ldots & \ldots & \ldots \\
r_{x_{p} x_{1}} & r_{x_{p} x_{2}} & \cdots & r_{x_{p} x_{p}}
\end{array}\right) \text { (8) }
$$

The multicollinearity can be confirmed by calculating the matrix determinant (8). If the independent variables are not related, the offdiagonal elements are equal to zero, and the matrix determinant is equal to unity. If the relationship between the independent variables is close to the functional correlation, the matrix determinant $r_{x} r$ will be close to zero $[12 ; 13 ; 14]$. 
According to Table 1, the matrix of predictor intercorrelation was as follows (9):

$$
\boldsymbol{r}_{\boldsymbol{x} x}=\left(\begin{array}{ccc}
1 & 0,916 & 0,955 \\
0,916 & 1 & 0,908 \\
0,955 & 0,908 & 1
\end{array}\right)(9)
$$

The matrix determinant was 0.013 , which was less than 1. Nevertheless, the determinant was different from zero, so it was necessary to apply other features of multicollinearity. Variables are considered to be included in the model, if relations (10) are satisfied, i.e. the strength of the relationship between response and explicative variables is greater than the strength of the relationship between explicative variables.

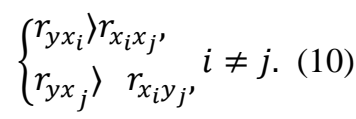

We used the data in Table 2 and obtained $r\left(y x_{1}\right)$ $=0.941 ; r\left(y x_{2}\right)=0.960$; and $r\left(y x_{3}\right)=0.933$.

Given the data in matrix (10), we have (11); (12); and (13)

$$
\left\{\begin{array}{l}
\left.r_{y x_{1}}=0.941\right\rangle r_{x_{1} x_{2}}=0.916 \\
\left.r_{y x_{2}}=0.960\right\rangle r_{x_{1} y 2}=0.916,
\end{array} i \neq j ;\right.
$$

Therefore, variables $x_{1}$ and $x_{2}$ can be included in the model

$$
\left\{\begin{array}{l}
\left.r_{y x_{2}}=0.960\right\rangle r_{x_{1} x_{3}}=0.955, \\
r_{y x_{3}}=0.933\left\langle r_{x_{1} x_{3}} 0.955,\right.
\end{array} i \neq j ;\right.
$$

and variable $x_{3}$ together with variable $x_{2}$ cannot be included in the model.

$$
\left\{\begin{array}{l}
r_{y x 1}=0.941\left\langle r_{x_{1} x_{3}}=0.955,\right. \\
r_{y x_{3}}=0.933\left\langle r_{x_{1} x_{3}} 0.955,\right.
\end{array} i \neq j .\right.
$$

therefore, the variable $x_{3}$ together with the variable $x_{l}$ cannot be included in the model.

Another method to measure multicollinearity resulted from the analysis of the standard error formula for the regression coefficient (14):

$$
S_{\sigma_{i}}=\frac{\sigma_{y}}{\sigma_{x_{j}}} \sqrt{\frac{1-R^{2} y x_{1} \ldots x_{p}}{\left(1-R^{2} x_{j} x_{1 \ldots} x_{j-1, \ldots} x_{p}\right)(n-m-1)}}
$$

As follows from this formula, the larger is the standard error, the smaller is the value of the variance inflation factor (VIF) (15):

$$
V I F_{x_{j}}=\frac{1}{\left(1-R^{2} x_{j} x_{1 . .} x_{j-1 \ldots} x_{p}\right)}
$$

where $\mathrm{R}^{2} x_{\mathrm{j}} x_{1 \ldots} x_{\mathrm{j}-1 \ldots} x_{\mathrm{p}}$ is the determination coefficient found in the stimulus-response equation for variable $x_{j}$ that depends on other variables $x_{1} \ldots x_{\mathrm{p}}$ in the considered multiple regression model $[12,13]$.

Value $\mathrm{R}^{2} x_{\mathrm{j}} x_{1 \ldots} x_{\mathrm{j}-1 \ldots} x_{\mathrm{p}}$ reflects the strength of the relationship between variable $x_{j}$ and other explicative variables and, in fact, characterizes multicollinearity with respect to variable $x_{j}$. If the relationship is absent, the $V I F_{x}$ indicator is equal (or closes) to unity; strengthening relationship makes this indicator tend to infinity. If $V I F_{x}>3$ for each variable, the multicollinearity occurs.

$$
\begin{aligned}
& V I F_{x_{1}}=\frac{1}{(1-0.925)}=\frac{1}{0.075}=13.3 \\
& V I F_{x 2}=\frac{1}{(1-0.851)}=\frac{1}{0.149}=6.7 \\
& V I F_{x 3}=\frac{1}{(1-0.825)}=\frac{1}{0.175}=5.7
\end{aligned}
$$

Calculations (16); (17); and (18) evidenced that the indices exceeded the significance point of three. Therefore, when constructing a model, the relationships between independent variables cannot be neglected.

This can be confirmed by following arguments. The State Program on Agribusiness Development envisages subsidizing the purchase of elite seeds until 2025 and guarantees the development of this sector. In the structure of sunflower production costs of agricultural producers, the costs of plant protection products enhanced from $10.0 \%$ in 2013 to $14.1 \%$ in 2018 . Given this trend, as well as the technological need to actively use chemicals at intensive sunflower production, we predicted an increase in the cost of protection products, which indicated the ability of this factor to have an impact on the crop yield in the medium term. It should be noted that in the Rostov Region from 2012 to 2018 , the share of imported seeds increased from $55.2 \%$ to $77.02 \%$. Thus, more than half of sunflower crops in the region depend on imported seeds that are highly germinated, resistant to diseases, and yielding. This fact is also in favor of the feature under consideration (Kholodov, 2020).

Consequently, the empirical basis we have considered for constructing a risk-sensitivity regression model of the sunflower yield was characterized by multicollinearity.

The presented multiple regression models contained input variables as predictors, most closely correlated with the yield value and had 
satisfactory quality characteristics. The factorial analysis results did not allow assessing the impact of all risk factors in the analysis on the sunflower yield; moreover, their specification was not unambiguous.

In this case, the list of independent variables cannot be changed; therefore, one of the methods for eliminating multicollinearity must be applied. For example, after correcting the model using the ridge regression equation procedure, the found parameter estimates will be biased (19) (Pechenevsky and Snegirev, 2018; Plis and Slivina, 1999; Pokrovsky, 2012):

$$
\mathrm{B}=\left(\mathrm{X}^{\mathrm{T}} \mathrm{X}+k \mathrm{I}\right)^{-1} \mathrm{X}^{\mathrm{T}} \mathrm{Y} \text {. }
$$

When building ridge regression, it is recommended to convert independent variables according to formula (20) and the response variable according to formula (21):

$$
\begin{gathered}
x_{i j}=\frac{x_{j}-\overline{x_{j}}}{\left.\sqrt{\sum\left(x_{j}\right.}-\bar{x}_{j}\right)^{2}} \\
y_{\tau}=y \times \overline{y_{\tau}} .
\end{gathered}
$$

Having evaluated the parameters (22), we found the regression of the initial variables, using relations (23):

$$
\begin{gathered}
a_{j}=\left(X_{\tau}{ }^{T} X_{\tau}+\tau I\right)^{-1} X_{\tau}{ }^{T} Y_{\tau} ;(22) \\
a_{j}=\frac{a_{i j}}{\sqrt{\sum\left(x_{j}-\overline{x_{j}}\right)^{2}}}, \mathrm{j}=1.2 \ldots, \mathrm{p} ; a_{0}=\bar{y} ; \sum_{j} a_{j} \overline{x_{j}} .
\end{gathered}
$$

Regression parameters estimated by formula (23) were biased. However, since the matrix determinant $\left(\mathrm{X}^{\mathrm{T}} \mathrm{X}+\tau \mathrm{I}\right)$ was greater than the matrix determinant $\left(\mathrm{X}^{\mathrm{T}} \mathrm{X}\right)$, the variance of the regression parameters estimates decreased and positively affected predicted properties of the model.

Thus, the task of our study resolves itself into this: using the same data set as when constructing Model 2, it is necessary to estimate the parameters of the ridge regression model that excludes the influence of multicollenarity and contains a full set of predictors.

In accordance with the above, the dependence of the parameters' estimates of the ridge-regression model on its values was initially studied. The empirical basis was the data in Table 2. The Mathcad package was used as a computational and analytical research tool. Taking into account the recommendations on the bias parameter value and the ridge regression results, the $\mathrm{k}$ parameter varied in the range from 0.25 to 3.0 , with the values of the determinant of the information XTX matrix being calculated together with the regression coefficients. To increase the accuracy of calculations, the factors were centered and normalized; the response was also centered (Pokrovsky, 2012).

The results of the simulation performed in the Mathcad mathematical package are shown in Table 6, where OLS estimates of the regression coefficients corresponding to $\mathrm{k}=0$; determination coefficients $R^{2}$, standard error, t-criteria, and $p$ levels of their significance were also to be found (Moiseev, 2017).

Table 6. Evaluation of ridge regression coefficients

\begin{tabular}{ccccccccccccc}
$K$ & $\begin{array}{c}\left(\mathrm{X}^{\mathrm{T}} \mathrm{X}+\right. \\
k \mathrm{I})^{-1} \mathrm{X}^{\mathrm{T}} \mathrm{Y}\end{array}$ & \multicolumn{1}{c}{$/$} & $b_{2}$ & $b_{3}$ & $t_{1}$ & $p_{1}$ & $t_{2}$ & $p_{2}$ & $t_{3}$ & $p_{3}$ & $\varepsilon$ & $R^{2}$ \\
\hline $\mathbf{0 . 0 0 0}$ & $\mathbf{2 . 8 3 3}$ & $\mathbf{0 . 8 0 3}$ & $\mathbf{1 . 8 7 5}$ & $\mathbf{0 . 5 8 5}$ & $\mathbf{0 . 5 0 5}$ & $\mathbf{0 . 6 4 6}$ & $\mathbf{1 . 6 6 8}$ & $\mathbf{0 . 1 9 4}$ & $\mathbf{0 . 3 8 4}$ & $\mathbf{0 . 7 2 3}$ & $\mathbf{1 . 0 6 3}$ & $\mathbf{0 . 9 4 7}$ \\
0.250 & 7.803 & 0.860 & 1.629 & 0.724 & 0.737 & 0.515 & 1.715 & 0.185 & 0.639 & 0.567 & 1.073 & 0.931 \\
0.500 & 15.118 & 0.890 & 1.486 & 0.789 & 0.918 & 0.429 & 1.771 & 0.174 & 0.831 & 0.469 & 1.089 & 0.916 \\
0.750 & 24.870 & 0.905 & 1.391 & 0.824 & 1.065 & 0.368 & 1.830 & 0.164 & 0.986 & 0.400 & 1.107 & 0.903 \\
$\mathbf{1 . 0 0 0}$ & $\mathbf{3 7 . 1 5 4}$ & $\mathbf{0 . 9 1 1}$ & $\mathbf{1 . 3 2 0}$ & $\mathbf{0 . 8 4 4}$ & $\mathbf{1 . 1 8 8}$ & $\mathbf{0 . 3 2 3}$ & $\mathbf{1 . 8 8 2}$ & $\mathbf{0 . 1 5 6}$ & $\mathbf{1 . 1 1 6}$ & $\mathbf{0 . 3 4 9}$ & $\mathbf{1 . 1 2 6}$ & $\mathbf{0 . 8 9 0}$ \\
1.250 & 52.062 & 0.913 & 1.265 & 0.855 & 1.295 & 0.289 & 1.934 & 0.148 & 1.226 & 0.311 & 1.146 & 0.877 \\
$\mathbf{1 . 5 0 0}$ & $\mathbf{6 9 . 6 8 9}$ & $\mathbf{0 . 9 1 1}$ & $\mathbf{1 . 2 2 1}$ & $\mathbf{0 . 8 6 0}$ & $\mathbf{1 . 3 8 8}$ & $\mathbf{0 . 2 6 1}$ & $\mathbf{1 . 9 8 1}$ & $\mathbf{0 . 1 4 2}$ & $\mathbf{1 . 3 2 2}$ & $\mathbf{0 . 2 8 0}$ & $\mathbf{1 . 1 6 7}$ & $\mathbf{0 . 8 6 5}$ \\
1.750 & 90.129 & 0.907 & 1.183 & 0.862 & 1.469 & 0.240 & 2.026 & 0.136 & 1.408 & 0.256 & 1.189 & 0.853 \\
2.000 & 113.475 & 0.902 & 1.150 & 0.861 & 1.542 & 0.222 & 2.065 & 0.131 & 1.483 & 0.236 & 1.211 & 0.842 \\
2.250 & 139.821 & 0.896 & 1.121 & 0.859 & 1.609 & 0.207 & 2.100 & 0.127 & 1.553 & 0.219 & 1.235 & 0.831 \\
2.500 & 169.260 & 0.889 & 1.095 & 0.855 & 1.668 & 0.194 & 2.135 & 0.123 & 1.613 & 0.206 & 1.259 & 0.820 \\
2.750 & 201.887 & 0.882 & 1.071 & 0.850 & 1.723 & 0.183 & 2.164 & 0.120 & 1.667 & 0.194 & 1.284 & 0.810 \\
3.000 & 237.796 & 0.874 & 1.050 & 0.844 & 1.769 & 0.175 & 2.194 & 0.117 & 1.719 & 0.184 & 1.310 & 0.800 \\
\hline
\end{tabular}

Source: author's calculations 
According to Table 6, centering and normalizing of the factors did not change the accuracy characteristics of the regression coefficients according to the "standard" OLS method $(\mathrm{k}=0)$. The only difference was that due to centering of the response variable, the $Y$-intercept of the model was equal to zero, and some differences in $p$ values of the regression coefficients were explained by calculation errors.

The regression equation (6) was presented in centered and normalized forms (24):

$$
Y=0.803 x_{1}+1.875 x_{3}+0.585 x_{5} \text {. }
$$

The determination coefficient of this model was 0.947; Fisher's test of 17.965 was significant at 0.020; and the standard approximation error was 1.06. Moreover, all factors were insignificant.

In practical estimation procedures, the initial decision-making methods for obtaining estimates of the regression coefficients are graphs, showing relationship between the variance in the coefficient estimates and changes in the bias parameter $k$ (ridge graphs). This parameter is usually not worth of considering. It is recommended to consider $k$ less than 0.5 and set a small step, for example, of 0.02. This recommendation, however, contradicts the results of ridge regression modeling presented in the Draper and Smith's classical work on the regression analysis, where the bias parameter value of 0.013 turned out to be the best according to the ridge graphs. The obtained value corresponded to the transition from the site of a strong change in the regression coefficients to the site of their slow change (Draper, Smith, 1987). In other works, the parameter values were greater, i.e. $\mathrm{k}=10$ (Moiseev, 2017).

To determine the best value of the bias parameter, we considered the ridge wake graphs presented in Figure 2. According to Figure 2a, the bias parameter increased from 0 to 1.0 , the coefficient of predictor "plant protection products applied per 1 ha" monotonously decreased, and the coefficients of the factors "proportion of imported sunflower seeds in the total area of crops" and "ratio of fields under elite seeds in the total area of crops" increased monotonously, the latter with saturation. When the range of variation of the bias parameter increased from 0 to 3.0 (Fig. 2b), the coefficient of the factor "ratio of fields under elite seeds in the total area of crops" reached the $k$ value in the range from 1.0 to 1.5 maximum, and the standard approximation error was in the range from 1.026 hundredweight/ha to 1.167 hundredweight/ha, i.e. only by $5.9 \%$... $9.8 \%$ more than in the case of the "classical" regression. Thus, the interval of the bias parameter can be considered optimal.

Models, corresponding to the boundaries of this interval of the displacement parameter, were presented in centered (25) and (26) and normalized forms (27) and (28):

$$
\begin{aligned}
& Y(k=1.0)=0.911 x_{1}+1.320 x_{3}+0.844 x_{5} \\
& Y(k=1.5)=0.911 x_{1}+1.221 x_{3}+0.860_{5} \\
& Y(k=1.0)=-5.652+4.28 x_{1}+9.040 x_{3}+0.060 x_{5} \\
& Y(k=1.5)=-5.284+4.218 x_{1}+8.3621 x_{3}+0.061_{5}
\end{aligned}
$$

Comparing models (25) and (26), on the one hand, and models (27) and (28), on the other, revealed the advantage of ridge regression models in a normalized form, i.e. in models (27) and (28), the regression coefficients did not depend on the predictors and were proportional to their contributions to the response variable-the deviation of the yield from the average value.

The calculations based on the data in Table 2 indicated that the reliability of the coefficients in the ridge regression models (27) and (28) was significantly higher than in the original model (6). The error rate of the regression coefficient with the factor "proportion of imported sunflower seeds in the total area of crops" decreased from $64.6 \%$ to $32.3 \%$ and $26.1 \%$ for models (27) and (28), respectively; with the factor "plant protection products applied per 1 ha" from $19.4 \%$ to $15.6 \%$ and $14.2 \%$; and with the factor "ratio of fields under elite seeds in the total area of crops" from $72.3 \%$ to $34.9 \%$ and $28.0 \%$. The quality of ridge regression models (27) and (28) did not decrease much. If the original model (6) was accounted for $94.7 \%$ of the total variance, models (27) and (28) were accounted for $89,0 \%$ and $86.5 \%$, respectively. 


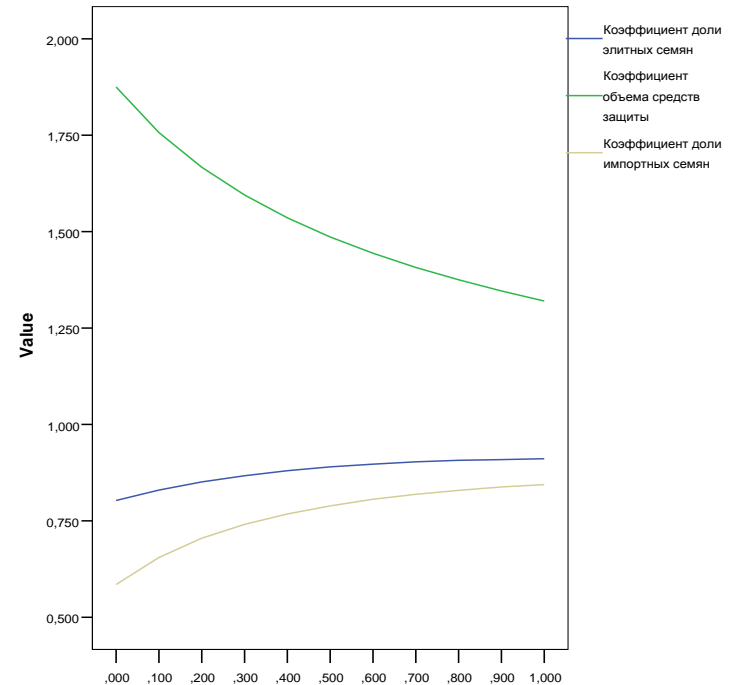

Bias parameter

$$
k=0 \ldots 1.0
$$

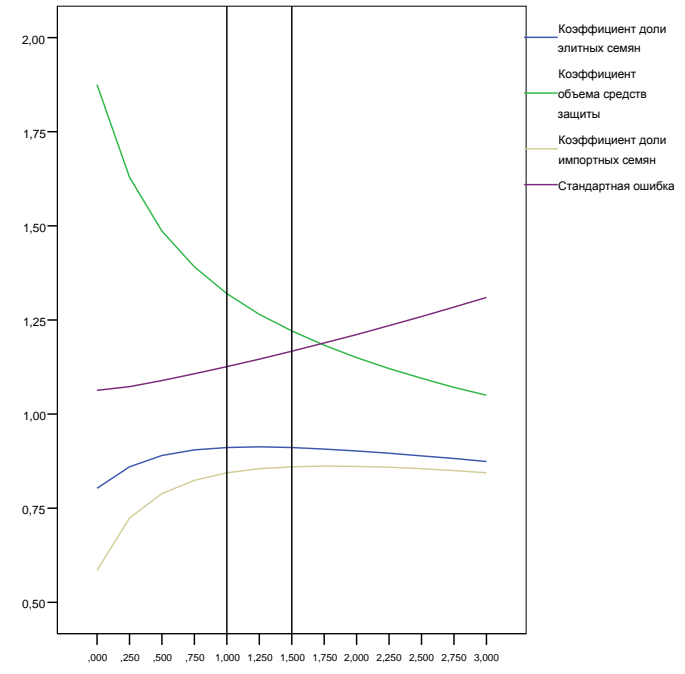

Bias parameter

$$
k=0 \ldots 3.0
$$

Figure 2. Relationship between ridge regression coefficients of sunflower yield and bias parameter in the range of a) from 0 to 1.0 ; and $b$ ) from 0 to 3.0.

Source: author's calculations

The conducted statistical analysis substantiated the econometric ridge regression models (27) and (28) to be useful for forecasting the sunflower yield for 2023. In order to increase the reliability, we used the average results for models (27) and (28) as predictive estimates.

Forecast values for the period of 2023 were determined using trend models and considered the recommendations of the Rostov Region Agriculture System (Table 7).
Table 7 shows that the ratio of fields under elite seeds in the total area of crops $\left(x_{1}\right)$ can make $3.4 \%$; plant protection products applied $\left(x_{2}\right)$ can make 0.94 $\mathrm{L}$ dose rate per $1 \mathrm{ha}$; and proportion of imported sunflower seeds in the total area of crops $\left(x_{3}\right) 93.3 \%$. With respect to the indicated values, the sunflower yield $(Y)$ in 2023 can make:

$$
\begin{aligned}
& Y(k=1.0)=-5.652+4.218 * 3.4+9.040 * 0.94+0.060 * 93.3=24.15(\text { Hundredweight } / \mathrm{ha}) \\
& Y(k=1.5)=-5.284+4.218 * 3.4+8.3621 * 0.94+0.061 * 93.3=21.57(\text { Hundredweight } / \mathrm{ha})
\end{aligned}
$$

Thus, the base predicted yield, depending on the factors studied, may be 22.9 hundredweight/ha $[(24.5+21.57) / 2]$.

Simulation modeling admits a possibility to introduce the effect of exogenous factors into extrapolation models and calculate the predicted value of the studied factors that affect the sunflower yield in the Rostov Region (Table 8). In conditions of depreciation of the national currency, the proportion of imported sunflower seeds in the total area of crops may be reduced to $85.0 \%$, and the amount of plant protection products applied may decrease to $0.9 \mathrm{~L}$ dose rate. At the same time, the ratio of fields under elite seeds in the total area of crops may increase to $5.0 \%$. In the case of a favorable macroeconomic situation in the country, we can assume that the ratio of fields under elite domestic seeds in the total area of crops may increase to $5.0 \%$; the amount of plant protection products applied up to $1.4 \mathrm{~L}$ dose rate; the proportion of imported sunflower seeds in the total area of crops up to $95.0 \%$ (Table 8 ). 
Table 7. Actual and forecast values of factors $(x)$

\begin{tabular}{cccc}
\hline Year & $x_{1}$ & $x_{2}$ & $x_{3}$ \\
2012 & 2.7 & Actual values & \\
2013 & 2.8 & 0.49 & 50.20 \\
2014 & 2.9 & 0.52 & 56.70 \\
2015 & 3.0 & 0.59 & 60.03 \\
2016 & 3.3 & 0.61 & 74.95 \\
2017 & 3.1 & 0.78 & 87.70 \\
2018 & 3.2 & 0.83 & 82.16 \\
& 3.4 & 0.80 & 77.02 \\
2023 & Forecast values & 93.3 \\
Relationship & Power & 0.94 & Logarithmic \\
\hline
\end{tabular}

Source: author's calculations

Table 8. Predicted sunflower yields for 2023 calculated by ridge regression and simulation modeling (for all categories of farms in the Rostov region)

\begin{tabular}{|c|c|c|c|}
\hline \multirow{3}{*}{ Parameter } & \multicolumn{3}{|c|}{ Predicted values } \\
\hline & \multirow{2}{*}{$\begin{array}{c}\text { Base } \\
\text { scenario }\end{array}$} & \multicolumn{2}{|c|}{ Simulation Scenario } \\
\hline & & Scenario I & Scenario II \\
\hline$x_{I}$ the ratio of fields under elite seeds in the total area of crops, $\%$ & 3.4 & 5.0 & 5.0 \\
\hline$x_{3}$ the plant protection products applied per 1 ha, $\mathrm{L}$, dose rate & 0.94 & 0.9 & 1.4 \\
\hline $\begin{array}{l}x_{5} \text { the proportion of imported sunflower seeds in the total area of } \\
\text { crops, } \%\end{array}$ & 93.3 & 85.0 & 95.0 \\
\hline $\begin{array}{l}Y \text { the average sunflower yield of seeds in weight after refinement, } \\
\text { hundredweight/ha }\end{array}$ & 22.9 & 28.6 & 33.5 \\
\hline Increase in yield, $\mathrm{kg} / \mathrm{ha}$ & - & +5.7 & +10.6 \\
\hline
\end{tabular}

Source: author's calculations

\section{CONCLUSIONS}

The calculation and analytical tools proposed to substantiate promising indices of sunflower production was based on data of a RF region and applied trend, regression, and simulation modeling, as well as different mathematical methods. Each of them can be applied separately.

The ridge regression calculations can be considered as an inertial scenario that suggests an increase in sunflower yield to $22.9 \mathrm{~kg} / \mathrm{ha}$ by 2023 , which was by $17.4 \%$ higher than the level of 2018 . The linear and non-linear trend models made it possible to substantiate the second moderate forecast scenario that implies an increase in sunflower yield to $26.5 \mathrm{~kg} / \mathrm{ha}$ by 2023 , which was by $35.9 \%$ higher than the level of 2018 . The ridge regression and simulation models represented the third optimistic scenario that predicted the sunflower yield of $33.5 \mathrm{~kg} / \mathrm{ha}$, which was by $71.8 \%$ higher than the level of 2018.

Developing the crop rotation structure, agricultural producers of the region take into account the recommendations of the Rostov Region Agriculture System; therefore, in the medium term, the sunflower area will not exceed $15.0 \%$ in the structure of sown areas, that is, approximately 700.0 thousand ha.

Thus, according to the first inertia scenario, the gross sunflower yield in 2023 may amount to 1603 thousand tons $(22.9 \mathrm{~kg} / \mathrm{ha} * 700.0$ thousand ha), which is by $16.3 \%$ higher than the level of 2018. The second moderate scenario suggested that the predicted gross sunflower yield may amount to 1855 thousand tons $(26.5 \mathrm{~kg} / \mathrm{ha} * 700.0$ thousand ha), which is by $34.6 \%$ higher than the level of 2018. The third optimistic scenario calculated by the ridge regression and simulation models testified that the maximum gross 
sunflower yield in the Rostov Region may reach 2345 thousand tons $(33.5 \mathrm{t} / \mathrm{ha} * 700.0$ thousand ha), which is by $70.1 \%$ higher than the level of 2018.

Using the example of forecasting the sunflower yield, it was substantiated that despite the functional multicollinearity of the predictors in the risk-sensitive yield model that is conditioned by the algorithm of the hierarchy analysis method used in the case of uncertainty of input variables, it was possible to provide a complete specification of the model and get biased but stable estimates of its parameters, using the ridge regression procedure. The rational value of the parameters was proposed to determine according to the ridge wake graphs as the border of fast and slow changes in the estimates of the ridge regression coefficients.

\section{ACKNOWLEDGMENTS}

This work was performed under RF President grant to support leading scientific schools, НШ2542.2020.11.

\section{REFERENCES}

DERUNOVA, E.A. Toolkit for assessing and predicting the dynamics of innovation and competitiveness of agricultural products. Econ. Agric. Proc. Enterprises, v.1, p.65-70, 2019.

DRAPER, N.; SMITH, H. Applied regression analysis. Part 2. Moscow: Finance and statistics, 1987.

GONCHAROV, V.D. Production of rapeseed oil in Russia: problems of development Econ. Agric. Proc. Enterprises, v.2, p.54-58, 2019.

GURNOVICH, T.G.; AGARKOVA, L.V.; OSTAPENKO, E.A.; USENKO, L.N. Increasing competitiveness of the agrarian sector of the heregional russian economy Russia. Int. J. Eng. Technol., v.7, p.201-211, 2018.
IVANOV, E.E.; SHUSTOV, D.A.; PERESHIVKIN, S.A. Multivariable statistical methods. Multiple regression analysis. Ridge regression method. 2020. Available in: http://ecocyb.narod.ru/513/MSM/msm3_2.htm. Accessed in: 15 Oct. 2020.

KABANOV, S.V. Using the Statistica 5.0 package for statistical processing of experimental data. 2020. Available in: http://www.exponenta.ru/educat/systemat/kabano v/literatura.asp. Accessed in: 15 Oct. 2020.

KHOLODOV, O.A. Development of industrial and economic relations between agricultural producers and processing enterprises. Fund. Appl. Res. Studies Econ. Coop. Sector, v.1, 2020.

KUZNETSOV, V.V.; TARASOV, A.N.; DUNAEV, V.L. et al. Improved forecasting of the regional agribusiness development based on economic and mathematical modeling. Rostov on Don: Vniiein, 2006.

MOISEEV, N.A. Comparative analysis of methods for eliminating multicollinearity. Acc. Sta., v.2, p.62-73, 2017.

PECHENEVSKY, V.F.; SNEGIREV, O.I. Forecasting the location of livestock production in the region. Econ. Agric. Proc. Enterprises, v.11, p.43-47, 2018.

PLIS, A.I.; SLIVINA, N.A. Mathcad: mathematical workshop for economists and engineers: a study guide. Moscow: Finance and Statistics, 1999.

POKROVSKY, A.M. Econometric models of sensitivity of innovative projects to risk factors based on ridge regression. Innovative Econ.Inf. Anal. Forecasts, v.3, p.10-13, 2012.

POLUSKINA, T.M. Modern Russia agrarian polity in the context of globalization. World Sci. Discov., v.1, p.105-115, 2013. 